\section{To: (Recelving Organization) \\ Distribution}

\section{Pro]./Prog./Dept./Div.:}

RPP Corrosion Probe

\section{Originator Remarks:}

This ETP desribes the activities associated with the installation of cabinets containing corrosion monitoring equipment on tanks 241-AN-102 and 241-AN-107.

\section{Recelver Remarks:}

11A. Design Baseline Document? $\bigcirc$ Yes

O No
4. Related EDT No.:
$\mathrm{N} / \mathrm{A}$
7. Purchase Order No.:
$\mathrm{N} / \mathrm{A}$
9. Equip./Component No.:
$\mathrm{N} / \mathrm{A}$
10. System/BIdg./Facility:
$\mathrm{N} / \mathrm{A}$
12. Major Assm. Dwg. No.:
$\mathrm{N} / \mathrm{A}$

13. Permit/Permit Application No.:

$\mathrm{N} / \mathrm{A}$

14. Required Response Date: N/A

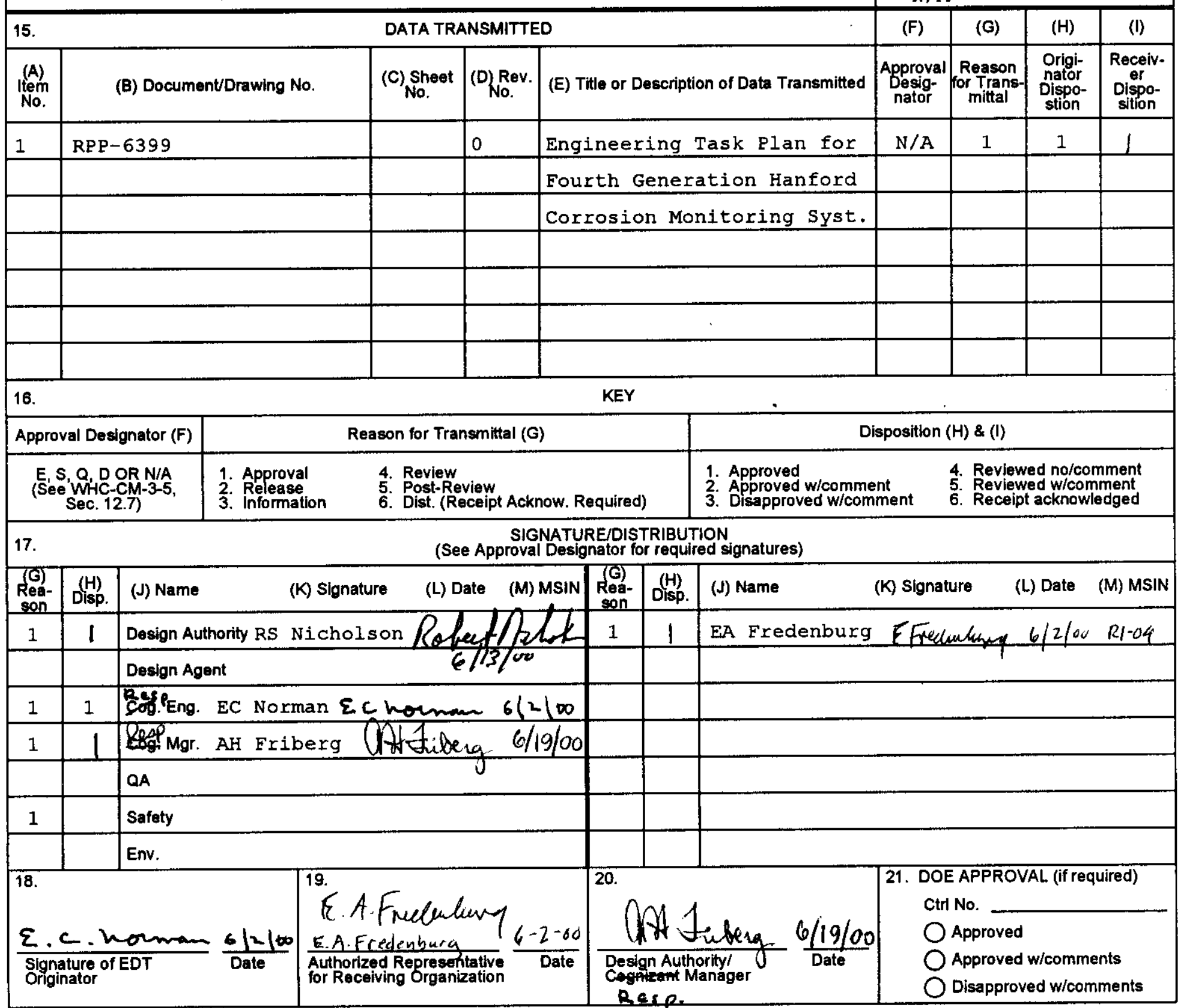




\title{
Engineering Task Plan for Fourth Generation Hanford Corrosion Monitoring System
}

\author{
g. C. Norman \\ CH2M HILL Hanford Group, Inc. \\ Richland, WA 99352 \\ U.S. Department of Energy Contract DE-AC06-96RL13200 \\ $\begin{array}{lll}\text { EDT/ECN: } & 629676 & \text { UC: } 2030 \\ \text { Org Code: } & 74700 & \text { Charge Code: } 112671 \\ \text { B\&R Code: } & \text { EW4010000 } & \text { Total Pages: } 9\end{array}$
}

Key Words: corrosion monitoring, corrosion probe, electrochemical noise, linear polarization resistance

Abstract: This Engineering Task Plan (ETP) describes the activities associated with the installation of cabinets containing corrosion monitoring equipment on tanks 241-AN-102 and 241-AN-107.

TRADEMARK DISCLAIMER. Reference herein to any specific commercial product, process, or service by trade name, trademark, manufacturer, or otherwise, does not necessarily constitute or imply its endorsement, recommendation, or favoring by the United States Government or any agency thereof or its contractors or subcontractors.

Printed in the United States of America. To obtain copies of this document, contact: Document Control Services, P.O. Box 950, Mailstop H6-08, Richland WA 99352, Phone (509) 372-2420; Fax (509) 376-4989.
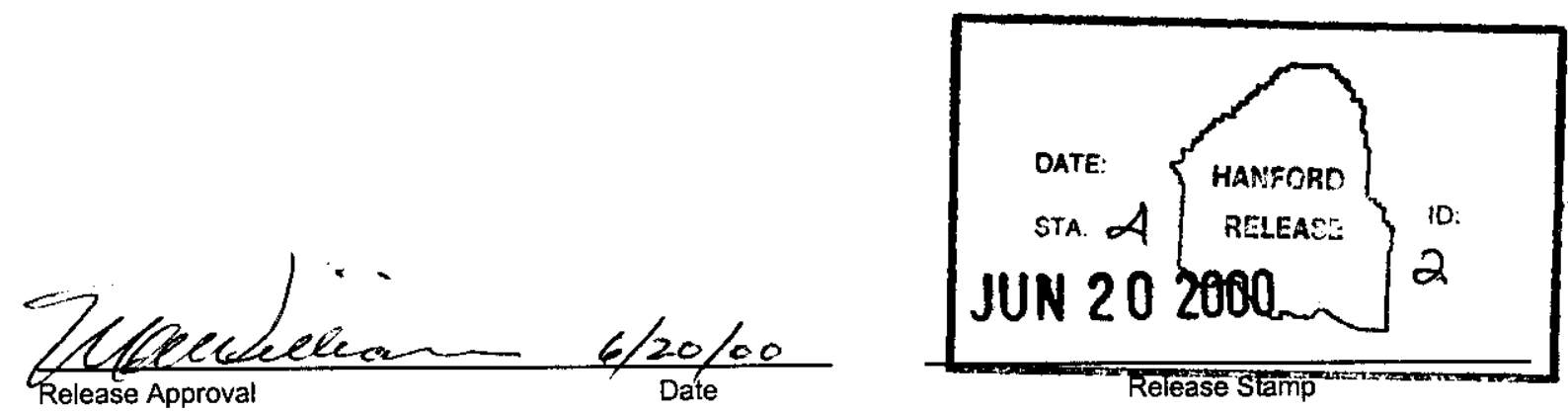
RPP-6399, Rev. 0

ENGINEERING TASK PLAN FOR FOURTH GENERATION

HANFORD CORROSION MONITORING SYSTEM

\author{
G. L. Edgemon \\ Hiline Engineering \& Fabrication, Inc. \\ 2105 Aviator Drive \\ Richland, Washington 99352
}


RPP-6399, Rev. 0

\section{ENGINEERING TASK PLAN FOR FOURTH GENERATION \\ HANFORD CORROSION MONITORING SYSTEM}

\subsection{INTRODUCTION}

This Engineering Task Plan (ETP) describes the activities associated with the installation of cabinets containing corrosion monitoring equipment on tanks 241-AN-102 and 241-AN-107. The new cabinets (one per tank) will be installed adjacent to existing corrosion probes already installed in riser WST-RISER-016 on both tanks. The corrosion monitoring equipment to be installed utilizes the technique of electrochemical noise (EN) for monitoring waste tank corrosion. Typically, EN consists of low frequency $(<1 \mathrm{~Hz})$ and small amplitude signals that are spontaneously generated by electrochemical reactions occurring at corroding or other surfaces. EN analysis is well suited for monitoring and identifying the onset of localized corrosion, and for measuring uniform corrosion rates. A typical EN based corrosion-monitoring system measures instantaneous fluctuations in corrosion current and potential between three nominally identical electrodes of the material of interest immersed in the environment of interest. Time-dependent fluctuations in corrosion current are described by electrochemical current noise, and timedependent fluctuations of corrosion potential are described by electrochemical noise. The corrosion monitoring systems are designed to detect the onset of localized corrosion phenomena if tank conditions should change to allow these phenomena to occur.

In addition to the EN technique, the systems also facilitate the use of the Linear Polarization Resistance (LPR) technique to collect uniform corrosion rate information. LPR measures the linearity at the origin of the polarization curve for overvoltages up to a few millivolts away from the rest potential or natural corrosion potential. The slope of the current vs. voltage plot gives information on uniform corrosion rates.

The cabinets to be installed are manufactured/assembled by Hiline Engineering and Fabrication in Richland, Washington. The data collection software/hardware systems are manufactured by Corrosion \& Condition Control, Ltd, Dingwall, Ross shire, U. K. The design of the corrosion monitoring system for each tank has been reviewed by the Hanford Site Flammable Gas Equipment Advisory Board and is bounded by report FGEAB-97-040, Rev. 2.

The installation of the new cabinets serves the purpose of moving the data collection equipment closer to the corrosion probes to improve data quality. The corrosion monitoring systems in tanks 241-AN-107 and 241-AN-102 were originally installed in 1997 and 1998 respectively. As originally configured, data collection hardware was located several hundred feet from the corrosion probes. Data quality with this configuration was poor. New cabinet placement is expected to rectify this problem.

\subsection{SCOPE}

\subsection{Objective}

The objective of this task is to install two new climate-controlled cabinets containing new 
corrosion monitoring hardware on top of tanks 241-AN-107 and 241-AN-102 (one cabinet per tank). The new hardware will be connected to existing corrosion monitoring probes already installed in riser WST-RISER-016 of tank 241-AN-107 and riser WSTRISER-016 of tank 241-AN-102. Equipment in the new cabinets will be linked (via Belden 9842 cable) to data collection computers already installed in the 241-AN-271 instrument building.

\subsection{Deliverables}

A new climate controlled cabinet containing corrosion monitoring hardware will be installed adjacent to riser WST-RISER-016 on tank 241-AN-107. A new climate controlled cabinet containing corrosion monitoring hardware will be installed adjacent to riser WST-RISER-016 on tank 241-AN-102. Both systems will be tied back to computers configured to collect corrosion monitoring data installed in the 241-AN-271 instrument building.

Installation tasks will involve placement of cabinets in field and all necessary trenching and conduit installation necessary to get power to the cabinets from a source in the 241AN-271 instrument building and data from the cabinets back to the computers in the 241AN-271 instrument building.

Deliverables consist of the following:

2.2.1 Activity supporting documentation including an Engineering Task Plan, Process Test Plan, engineering drawings, Acceptance Test Plan, Acceptance Test Report, As Low As Reasonably Achievable Management Work Sheets (as required), and Unreviewed Safety Question (USQ) Screenings (as required).

2.2.2 Two new climate-controlled, weather-resistant cabinets and all hardware, conduit, cables, and components necessary to operate the corrosion monitoring equipment that the cabinets will contain.

\subsection{DESCRIPTION}

\subsection{Physical Description}

Each cabinet to be installed is a six foot tall electronics cabinet designed for outdoor service, complete with $110 \mathrm{~V}$ cooling systems. Two cabinets will be used for this job. One cabinet will be installed by riser WST-RISER-016 on tank 241-AN-107. An identical cabinet will be installed by riser WST-RISER-016 on tank 241-AN-102. Each cabinet provides space to rack mount corrosion monitoring hardware and eight channels of intrinsic safety barriers necessary for data collection from an existing corrosion probe. Each cabinet also contains battery backup equipment for the corrosion monitoring hardware. Each cabinet comes with the necessary cables to connect to the existing corrosion probe and back to its associated corrosion monitoring computer in the 241-AN- 
271 instrument building. Each cabinet is wired and tested in accordance with UL standards prior to shipment. Each cabinet comes with a unistrut frame and portable concrete footings to aid in rapid installation.

In addition to cabinet installation on tanks $241-\mathrm{AN}-107$ and 241-AN-102, field trenching and conduit installation will be necessary to link cabinets back to the 241-AN-271 instrument building. It is expected that existing conduit will be utilized when possible and new conduit will be installed only as necessary. Appropriate ECNs and USQs will be prepared as necessary to facilitate and document changes in the field associated with this activity.

\subsection{Procurement}

The corrosion monitoring cabinets are manufactured by Hiline Engineering and Fabrication, Inc. of Richland Washington and are available as catalog item 0004-CHM072-C01. These cabinets have been procured as general service equipment and will be subject to QA receipt inspection by a certified National Electric Code (NEC) qualified inspector.

\subsection{Testing}

Testing of the corrosion monitoring cabinets will consist of the performance of an approved Acceptance Test Plan prior to field installation. Testing will be performed prior to shipment of the cabinets to the site. Once installed, corrosion monitoring systems will be operated by the responsible engineering organization under an approved Process Test Plan until operation can be turned over to site operations personnel.

\subsection{Installation}

Appropriate Operations personnel will complete installation with technical support from the appropriate engineering personnel. Installation will not commence until all installation work package documentation is approved per site standard procedures.

\subsection{SYSTEM FUNCTIONAL PERFORMANCE DESCRIPTION}

\subsection{New Corrosion Monitoring Cabinets}

New cabinets are expected to provide weathertight, climate-controlled housing for corrosion monitoring equipment. Corrosion monitoring equipment will be connected (following installation) to existing corrosion probes in tanks 241-AN-107 and 241-AN102. Corrosion monitoring equipment will be subjected to an approved acceptance test procedure prior to delivery. Once installed, the corrosion monitoring systems will be operated by the appropriate engineering organization under approved process test procedures. 


\subsection{ORGANIZATIONAL RESPONSIBILITIES}

Equipment Engineering under $\mathrm{CH} 2 \mathrm{M}$ Hill Hanford Group, Inc. will be responsible for directing the installation activities associated with the two new cabinets described in this ETP. Support organizations identified in this plan will provide ancillary support necessary to ensure successful completion of this activity. Functional responsibilities for the personnel and organizations will be as stated in this section.

5.1 CH2M Hill Hanford Group, Inc - Equipment Engineering - (E. C. Norman, E. A. Fredenburg, J. L. Castleberry)

Equipment Engineering will be responsible for overall activity management. Activity management shall include the following:

5.1.1 Generation and release of an Engineering Task Plan

5.1.2 Generation and release of an Acceptance Test Plan

\subsubsection{Generation and release of an Acceptance Test Report}

\subsubsection{Generation and release of a Process Test Plan}

5.1.5 Generation and release of necessary ECNs to facilitate and document changes to field configuration of equipment in the 241-AN farm and associated structures.

5.1.6 Generation and release of necessary USQ screenings to facilitate and document changes to field configuration of equipment in the 241-AN farm and associated structures.

5.1.7 Provide activity management, coordination and direction on the installation of the corrosion monitoring cabinets and related components.

5.1.8 Overall activity scheduling and budget development.

5.1.9 Provide input on site design, as required.

5.1.10 Provide coordination with other activities tied to the corrosion monitoring cabinet installation.

5.1.11 Serve as (or appoint) technical lead during field installation of cabinets.

5.1.12 Perform the cognitive engineering functions associated with all structures, systems, and components installed by this activity.

5.1.13 Provide input and interface with related systems or activities such as 
electrical, Operations, crafts, etc.

5.1.14 Provide general guidance and direction on site work.

5.1.15 Provide direction for work package preparation and assistance as required to ensure installation success.

5.1.16 Accept primary engineering responsibility and ownership of the corrosion monitoring systems after installation.

\subsection{East Tank Farms Production Control - (W. D. Bancroft)}

East Tank Farms Production Control will provide planner/scheduling support for the site preparation and installation of the new corrosion monitoring cabinets, conduit, cabling and other associated equipment. The following are the major responsibilities of East Tank Farms Production Control and may not be all-inclusive.

5.2.1 Provide work instructions for craft personnel for the installation of ancillary equipment in the tank farm.

5.2.2 Provide the preparation, planning, scheduling and performance of the Job Control System work package for fieldwork plans and instrument installation activities.

\subsection{East Tank Farms Operations Field Support - (D. L. Sparks)}

East Tank Farms Operations Field Support will provide Operations support for the installation of the new corrosion monitoring cabinets, conduit, cabling and other associated equipment. Operations will be responsible for the following:

5.3.1 Installation of the new corrosion monitoring cabinets, conduit, cabling and other associated equipment on tanks 241-AN-107 and 241-AN-102.

5.3.2 Providing resources to complete the work packages and field installations as required.

\subsection{Design Authority - (R. S. Nicholson)}

The Design Authority will verify that the planned activities and equipment meet all associated Authorization Basis and other miscellaneous requirements. The Design Authority will also provide review and approval for activities. Specific technical information is to be obtained from the Equipment Engineering organization within CH2M Hill Hanford Group, Inc. 


\subsection{DOCUMENTATION}

The following documentation in support of this activity was completed prior to the generation of this ETP:

1) G.L. Edgemon and G.E.C. Bell, Technical Basis for Electrochemical Noise Based Corrosion Monitoring of Underground Nuclear Waste Storage Tanks, Westinghouse Hanford Company Report, WHC-SD-WM-TI-772, November, 1996.

2) G.L. Edgemon, J.L. Nelson, P.C. Ohl, and G.E.C. Bell, Hanford Prototype Corrosion Probe Operational Experience, CORROSION/97, paper no. 97124, (Houston, TX: NACE International, 1997).

3) G.L. Edgemon, J.L. Nelson, and G.E.C. Bell, Design of an Electrochemical Noise Based Corrosion Monitoring Probe for High Level Nuclear Waste Storage Tanks, CORROSION/98, paper no. 98175, (Houston, TX: NACE International, 1998).

4) G.L. Edgemon and J. L. Nelson, Design of Second-Generation Corrosion Monitoring Probe, Lockheed Martin Hanford Company Report, HNF-2517, Rev. 0, April, 1998.

5) G.L. Edgemon, Design of Multi-Function Hanford Tank Corrosion Monitoring System, Lockheed Martin Hanford Company Report, HNF-4285, Rev. 0, April, 1999.

6) H. P. Shrivastava, Structural Evaluation of Second Generation Double Shell Tank Corrosion Probe Tree, Lockheed Martin Hanford Company Report, HNF-SD-WM-CN090, Rev. 0, June, 1997.

7) H. S. Ziada, Analysis of the Effects of Corrosion Probe on Riser 241-AN-102-WST-16 During Seismic Event, Numatec Hanford Company Report, HNF-3162, Rev. 0, November, 1998.

8) C. C. Scaief III, Flammable Gas Equipment Advisory Board Interpretation/ Recommendation Report - Corrosion Monitoring System, FGEAB-97-040. Rev. 2, Lockheed Martin Hanford Corporation, May, 1998.

\subsection{SCHEDULE}

All hardware will be ready for installation by August, 2000. All work package preparation work, field preparation work and a system Acceptance Test Plans shall be completed prior to installation of the new corrosion monitoring cabinets, conduit, cabling and other associated equipment.. Activity will be complete upon successful installation of the new corrosion monitoring cabinets, conduit, cabling and other associated equipment. 


\subsection{COST ESTIMATE}

\begin{tabular}{|ll|l|c|}
\hline \multicolumn{2}{|c|}{ Task } & \multicolumn{1}{c|}{ Responsible Organization } & Funding Requirements \\
\hline 1. & Activity Lead & $\begin{array}{l}\text { CH2M Hill Hanford Group } \\
\text { Inc. Equipment Engineering }\end{array}$ & $\$ 25 \mathrm{~K}$ \\
\hline 2. & Safety Support & Safety & $\$ 1 \mathrm{~K}$ \\
\hline 3. & Work Package & Production Control & $\$ 5 \mathrm{~K}$ \\
\hline 4. & Quality Assurance & Quality Assurance & $\$ 1 \mathrm{~K}$ \\
\hline 5. & Quality Control & Quality Control & $\$ 1 \mathrm{~K}$ \\
\hline 6. & $\begin{array}{l}\text { Ops, HPT, Crane and } \\
\text { Rigging Support }\end{array}$ & $\begin{array}{l}\text { Ops, HPT, Crane and } \\
\text { Rigging Organizations }\end{array}$ & $\$ 10 \mathrm{~K}$ \\
\hline 7. & Site Support -Crafts & East Tank Farms Crafts & $\$ 2 \mathrm{~K}$ \\
\hline & TOTAL & & $\$ 45 \mathrm{~K}$ \\
\hline
\end{tabular}

\subsection{QUALITY ASSURANCE}

Quality Assurance will provide the appropriate reviews and support of documentation, test procedures, and work packages. Cabinets will be inspected by a certified NEC inspector prior to their delivery to the site.

\subsection{SAFETY}

The appropriate Safety Organization(s) will provide reviews and support of documentation, test procedures, and work packages. 


\section{DISTRIBUTION SHEET}

To

Distribution

Project Title/Work Order

RPP-6399, Engineering Task Plan for Fourth Generation Hanford

Corrosion Monitoring System

Name

EA Fredenburg

EC Norman

RS Nicholson

JL Castleberry

GL Edgemon
From

Equipment Engineering

MSIN

R1-04

R1-04

S5-05

$\mathrm{R} 1-56$

R3-83
Page 1 of 1

Date June 2, 2000

EDT No. 629676

ECN No.

\begin{tabular}{|c|l|c|c|}
$\begin{array}{c}\text { Text } \\
\text { With All } \\
\text { Attach. }\end{array}$ & Text Only & $\begin{array}{c}\text { Attach./ } \\
\text { Appendix } \\
\text { Only }\end{array}$ & $\begin{array}{c}\text { EDT/ECN } \\
\text { Only }\end{array}$ \\
\hline $\mathrm{X}$ & & & \\
$\mathrm{X}$ & & & \\
\hline $\mathrm{X}$ & & & \\
\hline $\mathrm{X}$ & & & \\
$\mathrm{X}$ & & & \\
\hline
\end{tabular}

